\title{
Composition, Structure, and Bioactive Components in Milk Fat Globule Membrane
}

\author{
Yu-Jin Ahn, Palanivel Ganesan, and Hae-Soo Kwak* \\ Department of Food Science and Technology, Sejong University, Seoul 143-747, Korea
}

\begin{abstract}
A unique biophysical membrane which surrounds the milk fat globules is called the milk fat globule membrane (MFGM). Various researches were studied about origin, composition, structure and bioactive components of MFGM. Bioactive protein components of MFGM play an important beneficiary function such as defense mechanism in new born. Among the bioactive lipid components from MFGM phospholipids showed health enhancing functions. The phospholipids also help in the production of certain dairy product from deterioration. MFGM phospholipids also showed antioxidant activity in some dairy products such as butter and ghee produced from milk of buffalo. Based on the beneficial effects, researchers developed MFGM as functional ingredients in various food products. This current review focuses on health enhancing function of MFGM and its components in various dairy products.
\end{abstract}

Key words: milk fat globule membrane, bioactive protein, bioactive lipid

\section{Introduction}

Bioactive milk component refers to nonessential biomolecules in milk, exhibits the capacity to modulate one or more metabolic processes and also meets the need for mammal newborn (Lopez et al., 2010). These components are usually found in different forms in various dairy products. In fermented milk, milk, yogurt, butter and other milk products, these components are in the form of prebiotics, bioactive lipids and bioactive peptides. They have different metabolic activities which aid in curing of many diseases. Some research focus specifically on the bioactive components in milk fat globule membrane (MFGM) which are reported to be highly nutraceutical (Spitsberg, 2005).

MFGM composition and properties are varies from those of either milk or its components. The milk fat globules are more complex emulsion droplets because of their biological membrane, called the MFGM (Lopez et al., 2010). It is rich in proteins, enzymes, glycoproteins, phospholipids, sphingolipids, cholesterol and other minor components (Keenan and Patton, 1995; Lopez et al., 2010). It

*Corresponding author: Hae-Soo Kwak, Department of Food Science and Technology, Sejong University, Seoul 143-747, Korea. Tel: 82-2-3408-3226, Fax: 82-2-3408-4319, E-mail: kwakhs@sejong.ac.kr also acts as a natural emulsifying agent, which prevents fat globules coalescence in milk and prevents the enzymatic action on milk fat (Heid and Keenan, 2005). Their properties and its structure have various influences on the dairy products. Some of the MFGM components has anti-viral properties in buttermilk (Ochonicky et al., 2005). Buttermilk solids which are rich in MFGM showed antioxidant activity (Bilgin et al., 2006). Phospholipids of MFGM showed potential physiological effects on brain health (Kidd, 2000), against colon cancer, gastrointestinal pathogens (Spitsberg, 2005), cholesterol binding in vivo (Noh and Koo, 2004) and inhibition of tumour growth (Schmelz et al, 2003).

Both MFGM proteins and lipids have been proven to possess some unique health benefits and enhance the development of food characteristics in certain dairy foods. Based on the typical bioactive properties, MFGM could open a broad range of new means as health promoters in food and non food outlets. This review views on current research relating to the MFGM composition, structure, bioactive components and its role in various dairy products.

\section{Composition and Structure of MFGM}

\section{Composition}

Milk lipids are secreted in colloidal assemblies form 
called milk fat globules (MFGs). These particles have a size distribution ranging from about 0.1 to $10 \mu \mathrm{m}$ in bovine milk, with a mean diameter of around $4 \mu \mathrm{m}$. The milk fat globules contain complex compositions and structures which have many properties (Argov et al., 2008). The thin membrane encircled around the globules derived from the apical membrane of the lactating cells, called the MFGM (Bianchi et al., 2009). The membrane mass of MFGs varies from 2-6\% of total mass of fat globules (Lopez, 2010; Singh, 2006). MFGM consists of various components which includes proteins, lipids, enzymes, glycoproteins and other minor components (Danthine et al., 2000). The fat content and the size of globule in milk influence the amount and the composition of MFGM. It also depends on many factors such as diet, breed, health and stage of lactation of cows (Keenan, 2001; Keenan and Dylewski, 1995).

\section{Lipid composition of MFGM}

Various techniques have been used in analysis of lipid composition of bovine MFGM. Among the techniques thin-layer chromatography (TLC) and gas chromatography have been extensively used at early 1970 to late 1980 with poor resolution in MFGM analysis (Bracco et al., 1971; Fong et al., 2007; Hamzawi and Shahin, 1986; Kuchroo and Narayanan, 1981; Patton and Keenan, 1975; Ray and Singh, 1974; Sharma et al., 1987). The MFGM major lipid components are listed in Table 1. Among the total lipids, neutral lipids contribute a major amount which range from $56-80 \%$ in the MFGM. Triglycerides are the major section of neutral lipids ( $62 \%$ of total lipids) (Singh, 2006). A most of the triglycerides appear due to

Table 1. Lipid components of milk fat globule membrane ${ }^{\dagger}$

\begin{tabular}{lc}
\hline \hline \multicolumn{1}{c}{ Constituent class } & Total lipids (\%) \\
\hline Triglycerides & 62 \\
Diglycerides & 2.1 \\
Monoglycerides & 0.4 \\
Sterols & $0.2-2.0$ \\
Free fatty acids & $0.6-6.0$ \\
Phospholipids* & $26-31$ \\
Sphingomyelin & 25 \\
Phosphatidyl choline & 36 \\
Phosphatidyl enthanolamine & 30 \\
Phosphatidyl inositol & 11 \\
Phosphatidyl serine & 4 \\
Glucosyl-ceramide and lactosyl-ceramide & 6 \\
Lysophosphatidyl choline & 2 \\
\hline
\end{tabular}

* Phospholipid classes given as \% of total Phospholipids

${ }^{\dagger}$ Cited by (Keenan and Dylewski, 1995; Singh, 2006; Fong et al., 2007; Lopez et al., 2010) the contamination of core lipid during separation of the MFGM from fat globules (Walstra, 1985). The minor neutral lipids are diglycerides $(2.1 \%)$, esters $(0.1-0.8 \%)$ and cholesterol (0.2-6.1\%) (\% of total lipids) (Danthine et al., 2000; Vanderghem et al., 2010). A very little amounts of monoglyceride $(0.4 \%$ of the total lipid; Table 1$)$ were found in the MFGM samples. Further, it is not clear that these mono- and diglycerides are original composition of MFGM or derived by the lipolytic action of various enzymes during isolation of MFGM (Fong et al., 2007). Extensive amount of sterol and sterol esters were reported with cholesterol accounting for $90 \%$ of the total sterols (Jensen and Newberg, 1995).

Among the total lipids 15-43\% accounts for polar lipids such as phospholipids and sphingolipids in MFGM (Danthine et al., 2000). Among phospholipids, phosphatidyl choline(PC), phosphatidyl serine (PS) exist in zwittorionic form and some polar lipids such as phosphatidyl inositol (PI) and serine exist in anionic form (Dewettinck et al., 2008). Some minor sterols were also detected in MFGM, e.g. desmosterol, lathosterol by using GCMS technique (Fauquant et al., 2007).

\section{Protein composition of MFGM}

The MFGM protein composition ranged from 1-4\% among the total milk protein. Even though these proteins have a low nutritional value (Keenan and Patton, 1995), they have very important roles in defense mechanisms and various cellular processes in the newborn (Cavaletto et al., 2008). MFGM protein compositions are varied depending on the source (Danthine et al., 2000; Deeth, 1997; Dewettinck et al., 2008; Fong et al., 2007; Singh, 2006; Walstra et al., 2006).

The MFGM contains complex protein composition which composed of about 40 different proteins and their molecular mass ranges from 15,000 to $240,000 \mathrm{Da}$ (Mather, 2000; Riccio, 2004; Ye et al., 2002). The major and minor proteins of MFGM are listed in Table 2. Six of them are glycoproteins including mucin 1 (MUC 1), xanthin dehydrogenase/oxidase (XDH/XO), mucin 15 (MUC 15 or PAS III), CD36 (PAS IV), butyrophilin (BTN) and PAS 6/7 (lactadherin). The two other proteins, adipophilin (ADPH) and the fatty acid binding protein (FABP), are smaller and unglycosylated (Riccio, 2004). The major proteins are identified in past by comparison of electrophoretic mobilty by various staining of the gels. Modern proteomic approaches, including mass spectrometric (MS) analysis, provided rapid and unambiguous information on protein identity and further identification of minor pro- 
Table 2. Major and minor protein components of milk fat globule membrane $\uparrow$

\begin{tabular}{lc}
\hline \hline Proteins (Abbreviation) & Molecular weight (Da) \\
\hline Mucin 1 (MUC 1) & $160,000-200,000$ \\
Xanthin dehydrogenase/oxidase & 150,000 \\
$\quad$ (XDH/XO) & \\
Periodic acid Schiff (PAS III) & $95,000-100,000$ \\
Cluster of Differentiation (CD36) & $76,000-78,000$ \\
Butyrophilin (BTN) & 67,000 \\
Adipophilin (ADPH) & 52,000 \\
Periodic acid Schiff 6/7 (PAS 6/7) & $43,000-59,000$ \\
Fatty-acid binding protein (FABP) & 210,000 \\
Proteose peptone (PP3) & $18,000-30,000$ \\
$\beta$-glucuronidase inhibitor & Unknown \\
Helicobacter pylori inhibitor & Unknown \\
Phosphoproteins & Unknown \\
MFGM antigens & Unknown
\end{tabular}

$\bar{C}$ Cited by (Keenan and Dylewski, 1995; Mather, 2000; Singh, 2006; Dewettinck et al., 2008; Zamora et al., 2009) teins. Some human MFGM proteins were also identified by modern proteomic approach (Cavaletto et al., 2002; Charlwood et al., 2002; Quaranta et al., 2001). Some MFGM proteins are also reported by mass spectrometric (MS) analysis: two-dimensional gel electrophoresis (2DE) followed by reversed phase-LC-MS/MS (Fong et al., 2007) and various modern techniques (Lippolis, 2006; Vanderghem et al., 2008). Keenan et al. (2006) reported about 28 different enzymes in cows milk MFGM, e.g. catalase, aldolase. Some of these enzymes may come from the cytoplasmic crescents (Vandeghem et al., 2010).

\section{Structure of MFGM}

MFGM is composed of trilayer with approximate thickness of 10-50 nm. The inner mono layer of the membrane covers the core lipid, which originated from their endoplasmic reticulum and the triglyeceride rich core are

Table 3. Components of milk fat globule membrane associated with health benefits

\begin{tabular}{|c|c|c|}
\hline Component & Health benefit & Reference \\
\hline BRCA 1 & Inhibition of breast cancer & Spitsberg and Gorewit, 1997a \\
\hline BRCA 2 & Inhibition of breast cancer & Vissak et al., 2002 \\
\hline Fatty acid binding protein (FABP) & Cell growth inhibitor & $\begin{array}{l}\text { Spitsberg et al., 1995; } \\
\text { Spitsberg and Gorewit, 2002; Dewettinck et al., } \\
2008\end{array}$ \\
\hline Beta-glucuronidase inhibitor & Inhibition of colon cancer & Ito et al., 1993 \\
\hline FABP as selenium carrier & Anticancer factor & Bansal and Medina, 1993; Whanger, 2004 \\
\hline Helicobacter pylori inhibitor & Prevention of gastric diseases & Wang et al., 2001; Dewettinck et al., 2008 \\
\hline Cholesterolemia-lowering factor & Anticholesterolemic & Ito et al., 1992 \\
\hline Butyrophilin & Suppression of multiple sclerosis & Mana et al., 2004 \\
\hline Vitamin E and carotenoids & $\begin{array}{l}\text { Antioxidants } \\
\text { Anticancer } \\
\text { Anticholesterolemic }\end{array}$ & $\begin{array}{l}\text { Lindmark-Mansson and Akesson, 2000; Jensen and } \\
\text { Nielsen, 1996; Sen et al., 2006; Dewettinck et al., } \\
2008\end{array}$ \\
\hline Vitamin $\mathrm{K}$ & $\begin{array}{l}\text { Antiosteoporosis } \\
\text { Antiatherosclerosis } \\
\text { Antihepatocarcinoma }\end{array}$ & Kaneki et al., 2006 \\
\hline Xanthine oxidase & Bactericidal agent & Martin et al., 2004; Hancock et al., 2002 \\
\hline Phospholipids & $\begin{array}{l}\text { Inhibition of colon cancer } \\
\text { Anticholesterolemic } \\
\text { Suppression of gastrointestinal pathogens } \\
\text { Anti-Alzheimer, antidepressant } \\
\text { Antistress }\end{array}$ & $\begin{array}{l}\text { Parodi, } 2001 \\
\text { Noh and Koo, } 2004 \\
\text { Sprong et al., } 2002 \\
\text { Horrocks and Farooqui, } 2004 \\
\text { McDaniel et al., } 2003\end{array}$ \\
\hline Sphingolipid & $\begin{array}{l}\text { Age-related diseases } \\
\text { Anticholesterolemic } \\
\text { Bactericidal agent } \\
\text { Antiatherosclerosis } \\
\text { Hydrolysis of triacylglycerols and lipoprotein } \\
\text { synthesis in GI tract }\end{array}$ & $\begin{array}{l}\text { Parodi, 2001; Spitsberg, 2005; } \\
\text { Sprong et al., 2001, 2002, Lopez et al., } 2010\end{array}$ \\
\hline Phosphoproteins & Source of organic phosphorus and Ca-phosphate & Spitsberg and Gorewit, $1997 \mathrm{~b}$ \\
\hline MUC I & Immuno-protective role & Mather, 2000; Lopez, 2010 \\
\hline
\end{tabular}


in contact with membrane through hydrophobic tails of polar lipids of the inner membrane (Keenan and Patton, 1995; Vandeghem et al., 2010). Outer bilayer originates from the secretory cell apical membrane, where milk aqueous phase are in contact with the outer most polar hydrophilic lipid groups (Danthine et al., 2000; Vandeghem et al., 2010). Polar lipids are not homogenously organized in MFGM, some are located in inner surface, such as PE, PS and PI, where other phospholipids like PC, SM and glycolipids are concentrated in bilayer of MFGM (Lopez et al., 2008). The lipid droplets in MFGM aggregate and subsequently form large fat clumps known as butter after MFGM disturbed (Spitsberg, 2005). In the external membrane surface carbohydrate moieties are uniformly distributed (Danthine et al., 2000; Lopez et al., 2008). Proteins are like lipids arranged assymetrically, ADPH located inner polar lipid monolayer, XO in inner face monolayer, whereas BTN and ADPH are transmembrane proteins which form supramolecular complex which interconnects inner and outer membrane (Lopez, 2008; Mather and Keenan, 1998) and PAS6/7 located outside bilayer. The much detailed study of model is required since much of the MFGM components yet to be revealed.

\section{Bioactive components of MFGM}

MFGM components have been studied for a long time and continue to interest for its bioactive components and its beneficial roles in the human health (Spitsberg, 2005). Some of the health beneficial roles of proteins and phospholipids in bovine MFGM are reported (Riccio, 2004; Spitsberg, 2005) and it is shown in Table 3. Even though many studies reported the beneficial effects of MFGM, some of them reported a few putative effects (Riccio, 2004).

\section{Bioactive MFGM lipids}

Polar and complex lipids contained in the MFGM have been reported in various studies for its health strengthen functions (Bourlieu et al., 2009; Dewettinck, 2006; German and Dillard, 2006; Rombaut and Singh, 2006; Spitsberg, 2005). Inhibition of the proliferation of carcinoma cell lines was reduced by the bioactivity of phospholipids such as sphingomylin (Berra et al., 2002; Schmelz, 2003; Spitsberg, 2005). Some of the lipids are also associated in reduction of stress responses, age-related diseases, development of Alzheimer's disease and apoptosis (Parodi, 2001; Spitsberg, 2005). Inhibition of intestinal absorption of cholesterol and suppression of colon tumors are most effectively done by sphingomyelin (Lemmonnier et al., 2003; Noh and Koo, 2004). The vitamin K shows protective actions against hepatocarcinoma and atherosclerosis (Kaneki et al., 2006). The vitamins such as tocotrienols possess neuroprotective, anticancer and antioxidant activities (Sen et al., 2006).

\section{Bioactive MFGM proteins}

Bovine milk MFGM contains about 120 proteins (Reinhardt and Lippolis, 2006). Most of the proteins are involved in membrane/protein trafficking and cell signaling, and some of them are on fat transport and/or metabolism, protein synthesis, general transport and immune functions. Some of them have unknown functions. Their individual functions are listed in Table 4. Beyond their

Table 4. Function of major and minor proteins of milk fat globule membrane in milk

\begin{tabular}{|c|c|c|}
\hline Protein & Function & Reference \\
\hline Butyrophilin & $\begin{array}{l}\text { Glycoprotein consists of two extracellular immunoglobulin- } \\
\text { like domains. It has some receptorial function and modulates } \\
\text { the encephalitogenic } \mathrm{T} \text { cell response. Induce oral tolerance } \\
\text { and protect against development of multiple sclerosis }\end{array}$ & Cavaletto et al., 2002; Affolter et al., 2010 \\
\hline Carbonic anhydrase & $\begin{array}{l}\text { Essential factor in the normal growth and development of the } \\
\text { gastrointestinal tract of the newborn. }\end{array}$ & Karhumaa et al., 2001; Quaranta et al., 2001 \\
\hline Lactadherin & Promotes cell adhesion and is antiviral. & Quaranta et al., 2001; Affolter et al., 2010 \\
\hline Lactoferrin & $\begin{array}{l}\text { Inhibits the classical pathway of complement activation and } \\
\text { bacteriostatic action by competing with bacteria for iron. }\end{array}$ & Smolenski et al., 2007 \\
\hline Xanthine oxidase & $\begin{array}{l}\text { Involved in lipid globule secretion and defense protein and } \\
\text { indispensable for milk fat secretion. }\end{array}$ & Mather, 2000; Affolter et al., 2010 \\
\hline Mucin 1 & $\begin{array}{l}\text { Involved in protection against the attachment of fimbriated } \\
\text { microorganisms. }\end{array}$ & Affolter et al., 2010 \\
\hline Apidophilin and TIP47 & $\begin{array}{l}\text { Structural role for lipid droplet packaging and storage. } \\
\text { TIP47 involved in the trafficking of the mannose-6-phosphate } \\
\text { receptor. }\end{array}$ & Fong et al., 2007 \\
\hline Fatty acid binding protein & Regulation of lipid metabolism and inhibition of cell growth & Peterson et al., 1998; Affolter et al., 2010 \\
\hline
\end{tabular}


functions some of the MFGM protein has a beneficial role in health of human. For example, Mucin 1 protects the intestine of human by the prevention of attachment of fimbriated microbes. The MFGM enzyme such as carbonic anhydrase also plays as a vital role in the infant immunity (Quaranta et al., 2001). However, some article suggested the possible negative effect of some major protein in MFGM on human health like multiple sclerosis, coronary heart disease (Riccio, 2004). Further research should be focused before exploiting the results.

\section{Bioactive MFGM in dairy products}

Bioactive components of MFGM also involve in the development of certain dairy products. MFGM plays an important role in the development of milk based gel (Lopez and Dufour, 2001; Lucey et al., 1998; Michalski et al., 2002). It also enhances the texture (Lopez et al., 2007) and water holding capacity of certain cheese. MFGM also acts as a carbon source for lactic acid bacteria during ripening and increase the flavor in cheese by providing enzymes (Laloy et al., 1996; Lopez et al., 2007). Texture of ripened cheese was influenced by the microstructure of MFG, and its membrane MFGM enhances water holding capacity in Emmental cheese obtained from the native small MFG $(3 \mu \mathrm{m})$ than the Camembert cheese which made from large MFG $(6 \mu \mathrm{m})$. MFGM lysophospholipids also acts as surface-active agents in curds (Lilbaek et al., 2006). During the ripening of Cheddar cheese MFGM and its hydrolyzed components act as a carbon source for lactic acid bacteria (Laloy et al., 1996; Lopez et al., 2007). Intense flavor in cheeses was obtained from the proteolysis and lipolysis of MFGM enzymes.

MFGM also helps in prevention of excessive lipolysis and acts as a barrier which results in the reduction of rancid flavor in cheese (Mayes et al., 1994; Vanderghem et al., 2010). MFGM phospholipids are of excellent emulsifiers which prevent fat globules from their aggregation and coalescence in dairy emulsions (Sodini, 2006). Some of the phospholipids have antioxidant activity in buffalo butter (Hamzawi, 1990). It also acts an important factor in delaying the deterioration of ghee (clarified butter). Buttermilk added bread dough shows higher water absorption, increased resistance and better sensory score mostly due to the MFGM components (Bilgin et al., 2006; Vanderghem et al., 2010).

On the basis of health aspects, production of low fat yogurt, non-fat yogurt and other non-fat milk products result in the reduction of product quality due to the lower level of MFGM. The supplement of MFGM rich fraction results in enhancing the quality of low fat yogurt (Trachoo and Mistry, 1998). By means of MFGM, new yogurt or cheeses can be developed (Vanderghem et al., 2010). However, low fat in milk result in the reduction of MFGM which ultimately lower the level of bioactive component. The addition of processed MFGM may also result in different effects compared with the native MFGM (Vandeghem et al., 2010).

\section{Conclusion}

Recent advances in new methods and greater advancement in techniques result in the identification of bioactive components in utility of MFGM components. These also result in application of MFGM fractions in various food applications. Bioactive MFGM enhances the product quality in certain cheese such as Pizza cheese by reducing the meltability. The removal of fat results in the reduction of MFGM level which ultimately reduced the bioactive component availability in fat-reduced products. There is still a need to provide information about MFGM choices to consumers to aid in the selection of dairy components that contain optimal levels of health-promoting MFGM components. Further advanced research could explore more about the utility of MFGM components as a bioactive food ingredient.

\section{Acknowledgment}

This study was supported by a grant of the Brain Korea 21 Project in Seoul, Republic of Korea.

\section{References}

1. Affolter, M., Grass, L., Vanrobaeys, F., Casado, B., and Kussmann, M. (2010) Qualitative and quantitative profiling of the bovine milk fat globule membrane proteome. J. Proteomics 73, 1079-1088.

2. Argov, N., Lemay, D. G., and Germen, J. B. (2008) Milk fat globule structure and function: nanoscience comes to milk production. Trends Food Sci. Technol. 19, 617-623.

3. Bansal, M. and Medina. D. (1993) Expression of fatty acid binding proteins in the developing mouse mammary gland. Biochem. Biophys. Res. Commun. 191, 61-69.

4. Berra, B., Colombo, I., Sottocornola, E., and Giacosa, A. (2002) Dietary sphingolipids in colorectal cancer prevention. Eur. J. Cancer 1, 193-197.

5. Bianchi, L., Puglia, M., Landi, C., Matteoni, S., Perini, D., and Armini, A. (2009) Solubilization methods and reference 2-DE map of cow milk fat globules. J. Proteomics 72, 853864. 
6. Bilgin, B., Daglioglu, O., and Konyali, M. (2006) Functionality of bread made with pasteurized whey and/or buttermilk. Ital. J. Food Sci. 18, 277-286.

7. Bourlieu, C., Bouhallab, S., and Lopez, C. (2009) Biocatalyzed modications of milk lipids: applications and potentialities. Trends Food Sci. Technol. 20, 458-469.

8. Bracco, U., Hidalgo, J., and Bohren, H. (1971) Lipid composition of the fat globule membrane of human and bovine milk. J. Dairy Sci. 55, 165-171.

9. Cavaletto, M., Giuffrida, M. G., Fortunato, D., Gardano, L., Dellavalle, G., Napolitano, L., Giunta, C., Bertino, E., Fabris, C., and Conti, A. (2002) A proteomic approach to evaluate the butyrophilin gene family expression in human milk fat globule membrane. Proteomics 2, 850-856.

10. Cavaletto, M., Giuffrida, M. G., and Conti, A. (2008) Milk fat globule membrane components: a proteomic approach. Adv. Exp. Med. Biol. 606, 129-141.

11. Charlwood, J., Hanrahan, S., Tyldesley, R., Langridge, J., Dwek, M., and Camilleri, P. (2002) Use of proteomic methodology for the characterization of human milk fat globular membrane proteins. Anal. Biochem. 301, 314-324.

12. Danthine, S., Blecker, C., Paquot, M., Innocente, N., and Deroanne, C. (2000) Progress in milk fat globule membrane research: A review. Lait 80, 209-222.

13. Deeth, H. C. (1997) The role of phospholipids in the stability of milk fat globules. Aust. J. Dairy Technol. 52, 44-46.

14. Dewettinck, K., Rombaud, R., Thienpont, N., Trung Le, T., Messens, K., and Van Camp, J. (2008) Nutritional and technological aspects of milk fat globule membrane material. Int. Dairy J. 18, 436-57.

15. Fauquant, C., Briard-Bion, V., Leconte, N., Guichardant, M., and Michalski, M.-C. (2007) Membrane phospholipids and sterols in microfiltered milk fat globules. Eur. J. Lipid Sci. Technol. 109, 1167-1173.

16. Fong, B. Y., Norris, C. S., and MacGibbon, A. K. H. (2007) Protein and lipid composition of bovine milk-fat-globule membrane. Int. Dairy J. 17, 275-288.

17. German, J. B. and Dillard, C. J. (2006) Composition, structure and absorption of milk lipids: a source of energy, fat-soluble nutrients and bioactive molecules. Crit. Rev. Food Sci. Nutr. 46, 52-92.

18. Hamzawi, L. F. (1990) Role of phospholipids and á-tocopherol as natural antioxidants in buffalo butterfat. Milchwissenschaft 45, 95-97.

19. Hamzawi, L. F. and Shahin, Y. (1986) Fatty acid composition of milk fat globule membrane phospholipids from various species. Milchwissenschaft 41, 754-756.

20. Hancock, J. T., Salisbury, V., Ovejero-Boglione, M. C., Cherry, R., Hoare, C., Eisenthal, R., and Harrison. R. (2002) Antimicrobial properties of milk: Dependence on presence of xanthine oxidase and itrite. Antimicrob. Agents Chemother. 46, 3308-3310.

21. Heid, H. W. and Keenan, T. W. (2005) Intracellular origin and secretion of milk fat globules. Eur. J. Cell Biol. 84, 245258.

22. Horrocks, L. A. and Farooqui, A. A. (2004) Docosa- hexaenoic acid in the diets: Its importance in main and restoration of neural membrane function. Prostaglandins Leukot. Essent. Fatty Acids 70, 351-372.

23. Ito, O., Hotta, K., Goso, Y., Ishihara, K., Sugun, T., Morita, M., Wadstrom, T., and Schauer, K. (1993) Milk fat globule membrane substances inhibit mouse intestinal beta-glucuronidase. J. Food Sci. 58, 753-755.

24. Ito, O., Kamata, S., Hayashi, M., Suzuki, Y., Sakou, T., and Motoyoshi, S. (1992) Inhibitory effect of cream and milk fat globule membrane on hypercholesterolemia in the rat. Anim. Sci. Technol. (Japan) 63, 1022-1027.

25. Jensen, R. G. and Newberg, D. S. (1995) Bovine milk lipids. In: Handbook of milk composition. Jensen, R. G. (ed) Academic Press, NY, pp. 543-575.

26. Jensen, S. K. and Nielsen. K. N. (1996) Tocopherols, retinol, betacarotene and fatty acids in fat globule membrane and fat globule core in cows' milk. J. Dairy Res. 63, 565-574.

27. Kaneki, M., Hosoi, T., Ouchi, Y., and Orimo, H. (2006) Pleiotropic actions of vitamin K: Protector of bone health and beyond? Nutrition 22, 845-852.

28. Karhumaa, P., Leinonen, J., Parkkila, S., Kaunisto, K., Tapanainen, J., and Rajaniemi, H. (2001) The identification of secreted carbonic anhydrase VI as a constitutive glycoprotein of human and rat milk. P. Natl. Acad. Sci. USA, 11604-11608.

29. Keenan, T. W. (2001) Milk lipid globules and their surrounding membrane: a brief history and perspectives for future research. J. Mammary Gland Biol. Neoplasia 6, 365-71.

30. Keenan, T. W. and Dylewski, D. P. (1995) Intracellular origin of milk lipid globules and the nature of structure of milk fat globule membrane. In: Advanced dairy chemistry-Lipids. Fox P.F. (ed) Chapman and Hall, London, Vol. 2, pp.89-130.

31. Keenan, T. W. and Mather, I. H. (2002) Milk fat globule membrane. In : Encyclopedia of dairy sciences. Fuquay, J. W. and Fox, P. E. (eds) Academic Press, Amsterdam, pp. 1568-1576.

32. Keenan, T. W. and Mather, I. H. (2006) Intracellular origin of milk fat globules and the nature of the milk fat globule membrane. In: Advanced dairy chemistry- Lipids. Fox, P. F. and McSweeney, P. L. H. (eds) Springer, NY, Vol. 2, pp.137-171.

33. Keenan, T. W. and Patton, S. (1995) Handbook of Milk Composition. Jensen, R. G. (ed) Academic Press, CA, pp. 5-50.

34. Kidd, P. M. (2000) Dietary phospholipids as anti-aging nutraceuticals. In: Anti-aging medical therapeutics. Klatz, R. A. and Oldman, R. (eds) Health Quest, IL, Vol. 4, pp. 282300 .

35. Kuchroo, T. K. and Narayanan, K. M. (1981) Composition of fat globule membrane phospholipids. Indian J. Dairy Sci. 34, 88-90.

36. Laloy, E., Vuillemard, J. -C., El Soda, M. E., and Simard, R. E. (1996) Influence of the fat content of Cheddar cheese on retention and localization of starters. Int. Dairy J. 6, 729-740.

37. Lemmonnier, L. A., Diffehay, D. L., Vespreni, M. J., Abrams, J., Brody, E., and Schmelz, E. M. (2003) Sphingomyelin in the suppression of colon tumours: prevention and intervention. Arch. Biochem. Biophys. 419. 129-138.

38. Lilbaek, H. M., Broe, M. L., Hoier, E., Fatum, T. M., Ipsen, 
R., and Sorensen, N. K. (2006) Improving the yield of Mozzarella cheese by phospholipase treatment of milk. J. Dairy Sci. 89, 4114-4125.

39. Lindmark-Mansson, H. and Akesson. B. (2000) Antioxidative factors in milk. Br. J. Nutr. 84 (Suppl.), S103-S110.

40. Lopez, C. (2010) Lipid domains in the milk fat globule membrane: Specific role of sphingomyelin. Lipid Technol. 22, 175-178.

41. Lopez, C., Briard-Bion, V., Menard, O., Rousseau, F., Pradel, P., and Besle, J. -M. (2008) The phospholipid, sphingolipid and fatty acid compositions of the milk fat globule membrane are modified by diet. J. Agric. Food Chem. 56, 52265236.

42. Lopez, C., Camier, B., and Gassi, J.-Y. (2007) Development of the milk fat microstructure during the manufacture and ripening of Emmental cheese observed by confocal laser scanning microscopy. Int. Dairy J. 17, 235-247.

43. Lopez, C. and Dufour, E. (2001) The composition of the milk fat globule surface alters the structural characteristics of the coagulum. J. Colloid Interface Sci. 233, 241-249.

44. Lopez, C., Madec, M. N., and Jimenez-Flores, R. (2010) Lipid rafts in the bovine milk fat globule membrane revealed by the lateral segregation of phospholipids and heterogeneous distribution of glycoproteins. Food Chem. 120, 22-33.

45. Lucey, J. A., Munro, P. A., and Singh, H. (1998) Rheological properties and microstructure of acid milk gels as affected by fat content and heat treatment. J. Dairy Sci. 63, 660-664.

46. Mana, P., Goodyear, M., Bernard, C., Tomioka, R., FreireGarabal, M., and Linares, D. (2004) Tolerance induction by molecular mimicry: Prevention and suppression of experimental autoimmune encephalomyelitis with the milk protein butyrophilin. Int. Immunol. 16, 489-499.

47. Martin, H. M., Hancock, J. T., Salisbury, V., and Harrison. R. (2004) Role of xanthine oxidoreductase as an antimicrobial agent. Infect. Immun. 72, 4933-4939.

48. Mather, I. H. (2000) A review and proposed nomenclature for major proteins of the milk-fat globule membrane. $J$. Dairy Sci. 83, 203-247.

49. Mather, I. H. and Keenan, T. W. (1998) Origin and secretion of milk lipids. J. Mammary Gland Biol. Neoplasia 3, 259273.

50. Mayes, J. J., Urbach, G., and Sutherland, B. J. (1994) Does addition of buttermilk affect the organoleptic properties of low-fat cheddar cheese? Aust. J. Dairy Technol. 49, 39-41.

51. McDaniel, M. A., Maier, S. F., and Einstein. G. O. (2003) "Brainspecific" nutrients: A memory cure? Nutrition 19, 955-956.

52. Michalski, M. C., Cariou, R., Michel, F., and Garnier, C. (2002) Native vs. damaged milk fat globules: Membrane properties affect the viscoelasticity of milk gels. J. Dairy Sci. 85, 2451-2461.

53. Noh, S. K. and Koo, S. L. (2004) Milk sphingomyelin is more effective than egg sphingomyelin in inhibiting intestinal absorption of cholesterol and fat in rats. J. Nutr. 134, 2611-2616.

54. Ochonicky, K. L., Donovan, S. M., Kuhlenschmidt, T. B.,
Jiménez-Flores, R., and Kuhlenschmidt, M. S. (2005) Inhibitory activity of bovine milk fat globule membranes against sialic acid-dependent and independent strains of rotavirus. ADSA/ASAS/CSAS Joint Annual Meeting, Cincinnati, OH, USA.

55. Parodi, P. W. (2001) Cow's milk components with anti-cancer potential. Aust. J. Dairy Technol. 56, 65-73.

56. Patton, S. and Keenan, T. W. (1975) The milk fat globule membrane. Biochim. Biophys. Acta 415, 275-309.

57. Peterson, J. A., Hamosh, M., Scallan, C. D., Ceriani, R. L., Henderson, T. R., Mehta, N. R., Armand, M., and Hamosh, P. (1998) Milk fat globule glycoproteins in human milk and in gastric aspirates of mother's milk-fed preterm infants. Pediatr Res. 44, 499-506.

58. Quaranta, S. Giuffrida, M. G., Cavaletto, M., Giunta, C., Godovac-Zimmermann, J., Canas, B., Fabris, C., Bertino, E., Mombro, M., and Conti, A. (2001) Human proteome enhancement: high-recovery method and improved twodimensional map of colostral fat globule membrane proteins. Electrophoresis 22, 1810-1818.

59. Ray, T. K. and Singh, G. P. (1974) Lipid composition of milk fat globule membrane fractions. Proceed. XIX Int. Dairy Cong. Ottawa, Canada, pp. 211-212.

60. Reinhardt, T. A. and Lippolis, J. D. (2006) Bovine milk fat globule membrane proteome. J. Dairy Res. 73, 406-416.

61. Riccio, P. (2004) The proteins of the milk fat globule membrane in the balance. Trends Food Sci. Technol. 15, 458-61.

62. Rombaut, R. and Dewettinck, K. (2006) Properties, analysis and purification of milk polar lipids. Int. Dairy J. 16, 13621373.

63. Schmelz, E. M. (2003) Dietary sphingolipids in the prevention and treatment of colon cancer. In: Nutrition and Biochemistry of Phospholipids. Szuhaj, B. F. and van Nieuwenhuyzen, W. (eds) AOCS Press, IL, pp. 80-87.

64. Sen, C. K., Khanna, S., and Roy, S. (2006) Tocotrienols: Vitamin E beyond tocopherols. Life Sci. 78, 2088-2098.

65. Sharma, K. C., Kumari, A., Sareen, V. K., and Singh, S. (1987) Lipid composition of fat globule membranes from butter milk and butter serum of buffalo and cow milk. Milchwissenschaft 42, 439-442.

66. Singh, H. (2006) The milk fat globule membrane-A biophysical system for food applications. Curr. Opin. Colloid Interface Sci. 11, 154-163.

67. Smolenski, G., Haines, S., Kwan, F. Y., Bond, J., Farr, V., and Davis, S. R. (2007) Characterisation of host defence proteins in milk using a proteomic approach. J. Proteome Res. 6, 207215.

68. Sodini, I., Morin, P., Olabi A., and Jimenez-Flores, R. (2006) Compositional and functional properties of buttermilk: A comparison between sweet, sour, and whey buttermilk. $J$. Dairy Sci. 89, 525-536.

69. Spitsberg, V. L. (2005) Invited review: bovine milk fat globule membrane as a potential nutraceutical. J. Dairy Sci. 88, 2289-2294.

70. Spitsberg, V. L. and Gorewit, R. C. (1997a) Breast ovarian cancer susceptibility protein (BRCA1) in milk, tissue and 
cells. J. Dairy Sci. 80 (Suppl. 1), 60.

71. Spitsberg, V. L. and Gorewit, R. C. (1997b) In vitro phosphorylated bovine milk fat globule membrane proteins. J. Nutr. Biochem. 8, 181-189.

72. Spitsberg, V. L. and Gorewit, R. C. (2002) Isolation, purification and characterization of fatty-acid-binding protein from milk fat globule membrane: Effect of bovine growth hormone treatment. Pak. Nutr. 1, 43-48.

73. Spitsberg, V. L., Matitashvili, E., and Gorewit. R. C. (1995) Association of fatty acid binding protein and glycoprotein CD36 in the bovine mammary gland. Eur. J. Biochem. 230, 872-878.

74. Sprong, R. C., Hulstein, M. F. E., and Van der Meer, R. (2001) Bactericidal activities of milk lipids. Antimicrob. Agents Chemother. 45, 1298-1301.

75. Sprong, R. C., Hulstein, M. F. E., and Van der Meer, R. (2002) Bovine milk fat components inhibit food-born pathogens. Int. Dairy J. 12, 209-215.

76. Trachoo, N. and Mistry, V. V. (1998) Application of ultrafiltered sweet buttermilk and sweet buttermilk powder in the manufacture of nonfat and low fat yogurts. J. Dairy Sci. 81, 3163-3171.

77. Vanderghem, C., Blecker, C., Danthine, S., Deroanne, C., Haubruge, E., Guillonneau, F., De Pauw, E., and Francis, F. (2008) Proteome analysis of the bovine milk fat globule: enhancement of membrane purification. Int. Dairy J. 18, 885-893.

78. Vanderghem, C., Bodson, P., Danthine, S., Paquot, M., and
Blecker, C. (2010) Milk fat globule membrane and buttermilks: from composition to valorization. Biotechnol. Agron. Soc. Environ. 14, 485-500.

79. Vissak, C., Lemery, D., Le-Corre, L., Fustier, P., Dechelotte, P., Maurizis, J. C., Bignon, Y. G., and Bernard-Gallon. D. J. (2002) Presence of BRCA1 and BRCA2 proteins in human fat globules after delivery. Biochim. Biophys. Acta 1586, 5056.

80. Walstra, P. (1985) Some comments on the isolation of fat globule membrane material. J Dairy Res. 52, 309-12.

81. Walstra, P., Wouters, J. T. M., and Geurts, T. J. (2006) Dairy science and technology. Boca Raton, FL, USA.

82. Wang, X., Hirmo, S., Millen, R., and Wadstrom, T. (2001) Inhibition of Helicobacter pylori infection by bovine milk glycoconjugates in a BALB/cA mouse model. FEMS Immunol. Med. Microbiol. 20, 275-281.

83. Whanger, P. D. (2004) Selenium and the relationship to cancer: An up-date dagger. Br. J. Nutr. 9, 11-28.

84. Ye, A., Singh, H., Taylor, M. W., and Anema, S. (2002) Characterization of protein components of natural and heattreated milk fat globule membranes. Int. Dairy J. 12, 393402.

85. Zamora, A., Guamis, B., and Trujillo, A. J. (2009) Protein composition of caprine milk fat globule membrane. Small Rum. Res. 82, 122-129.

(Received 2010.10.1/Revised 2011.2.1/Accepted 2011.2.10) 